DOI 10.22460/jpmi.v1i2.93-218

\title{
PENGARUH KEMANDIRIAN BELAJAR TERHADAP KEMAMPUAN PENALARAN MATEMATIS SISWA PADA MATERI PERBANDINGAN
}

\author{
Ghina Nurul Zannati ${ }^{1}$, Aflich Yusnita Fitrianna ${ }^{2}$, Euis Eti Rohaeti ${ }^{3}$ \\ 1,2,3 IKIP Siliwangi Bandung, J1. Terusan Jenderal Sudirman, Cimahi, Jawa Barat, Indonesia \\ 1'ghina.hyuga@gmail.com, ${ }^{2}$ aflichyf@ikipsiliwangi.ac.id, ${ }^{3} \mathrm{e} 2 \mathrm{rht@stkipsiliwangi.ac.id}$
}

\begin{abstract}
This study aims to investigate how significant the ability of mathematical reasoning is influenced by the independence of learning on comparative materials. The method used in this study is correlational method with quantitative approach. The population in this study were students of SMP / MTs in Kota Cimahi and the samples were 30 students of MTs Al-Musyahadah Cimahi. The instrument in this research is a test of 6 questions about comparison of mathematical reasoning ability and 32 scale statements of scale self-learning. The data analysis technique, which was applied, is the prerequisite analysis test in the form of normality test and correlation test. The results of this study concluded that students' mathematical reasoning ability on comparison material is positively influenced by learning independence $57.33 \%$ and the remaining $42.67 \%$ is determined by other factors.
\end{abstract}

Keywords: Mathematical reasoning ability, the independence of learning

\begin{abstract}
Abstrak
Penelitian ini bertujuan untuk melihat pengaruhi kemandirian belajar terhadap kemampuan penalaran matematis pada materi perbandingan. Metode dalam penelitian ini menggunakan metode korelasi dengan pendekatan kuantitatif. Populasi dalam penelitian ini adalah siswa SMP/MTs di Kota Cimahi dan sampelnya sebanyak 30 orang di MTs Al-Musyahadah Cimahi. Instrumen dalam penelitian ini berupa tes kemampuan penalaran matematis sebanyak 6 butir soal materi perbandingan yang sudah divalidasi serta diuji cobakan dan skala kemandirian belajar sebanyak 32 skala pernyataan. Teknik analisis data yang digunakan yaitu berupa uji normalitas dan uji kolerasi. Hasil penelitian ini memperoleh kesimpulan bahwa, kemampuan penalaran matematis siswa pada materi perbandingan dipengaruhi positif oleh kemandirian belajarnya $57,33 \%$ dan sisanya $42,67 \%$ ditentukan oleh faktor lain.
\end{abstract}

Kata Kunci: Kemampuan Penalaran Matematis, Kemandirian Belajar

How to cite: Zannati, G. N., Fitrianna, A. Y, \& Rohaeti, E. E. (2018). Pengaruh Kemandirian Belajar Terhadap Kemampuan Penalaran Matematis Siswa pada Materi Perbandingan. JPMI - Jurnal Pembelajaran Matematika Inovatif, 1 (2), 107-112.

\section{PENDAHULUAN}

Aspek penting yang harus diperhatikan dalam proses pembelajaran adalah kemampuan penalaran matematis. Menurut Baroody dan Nasoetion (Hendriana, Rohaeti, Sumarmo: 2017) penalaran matematis sangat penting dalam membantu individu tidak sekedar mengingat fakta, aturan, dan langkah-langkah penyelesaian masalah, tetapi menggunakan keterampilan bernalarnya dalam melakukan pendugaan atas dasar pengalamannya bersangkutan akan memperoleh pemahaman konsep matematika yang saling berkaitan dan belajar secara 
bermakna atau meaningfull learning (Isnaeni, Fajriyah, Risky, Purwasih., \& Hidayat, 2018). Hidayat \& Prabawanto (2018) berpendapat bahwa berdasarkan tujuan pembelajaran matematika, menunjukkan bahwa kemampuan penalaran matematis merupakan kemampuan yang harus dikuasai peserta didik SMP/MTs dalam membuat generalisasi, menyusun bukti, atau menjelaskan gagasan dan pernyataan matematika. Kemampuan penalaran dalam pembelajaran matematika perlu dikembangkan, karena dapat membantu siswa meningkatkan kemampuan dalam matematika, yaitu dari yang hanya sekedar mengingat kepada kemampuan pemahaman). Juga menurut Zannati (2017) Pada indikator penarikan kesimpulan umum berdasarkan sejumlah data yang teramati, siswa dengan kemampuan tinggi masih keliru menarik kesimpulan penyebabnya sering terkecoh dalam menganalisa soal. Sedangkan siswa dengan kemampuan sedang, merasa kebingungan menganalisa soal sehingga untuk menarik sebuah kesimpulan masih perlu bimbingan. Siswa dengan kemampuan rendah hanya mampu memodelkan permasalahan dalam soal tanpa mengambil kesimpulan. Pada indikator menggunakan pola hubungan, menganalisa, dan mensintesa kasus dan menyusun konjektur, siswa dengan kemampuan tinggi tidak mengalami kesulitan. Siswa dengan kemampuan sedang, kesulitan dalam menganalisa penyebabnya masih keliru dalam menggunakan pola hubungan permasalahan. Sedangkan siswa dengan kemampuan rendah, masih perlu bimbingan untuk menemukan pola hubungan dalam mengambil kesimpulan. Pada indikator memperkirakan solusi, atau jawaban, interpolasi dan ekstrapoasi, siswa dengan kemampuan tinggi tidak mengalami kesulitan. Sedangkan siswa dengan kemampuan sedang dan rendah masih perlu bimbingan guru dikarenakan pemahaman materi yang sering dilupakan. Mullis, Martin, Ruddock, Sullivan, dan Preushchoff (Hendriana, Rohaeti, Sumarmo: 2017) merinci kemampuan penalaran matematis ke dalam beberapa indikator yaitu analisis, generalisasi, sintesis, pembuktian, dan pemecahan masalah tidak rutin.

Namun pada kenyataan di lapangan, siswa hanya menerima apa yang disajikan oleh guru dan sangat bergantung pada guru. Upaya untuk mencari informasi dari media lain sangat kurang. Oleh karena itu, kemandirian belajar diperlukan agar siswa mempunyai tanggung jawab dalam mengatur dan mendisiplinkan dirinya, serta dalam mengembangkan kemampuan belajarnya atas kemauan sendiri (Nuridawani, Said, Saiman: 2015). Hal ini sejalan dengan yang dikemukakan Darma, Y., M. Firdaus, R. Haryadi (2016) bahwa saat ini konsep tentang belajar matematika telah berubah dari pemberian suatu konsep dan prosedur secara pasif dan tidak kontekstual menjadi pembentukkan makna secara aktif sebagai hasil mengaitkan ide-ide baru pada pemahaman terdahulu. Mulyana (Hendriana, Rohaeti, Sumarmo: 2017) menyebutkan bahwa indikator kemandirian belajar terdiri dari inisiatif belajar, mendiagnosa kebutuhan belajar, menetapkan tujuan/target belajar, memandang kesulitan sebagai tantangan, memanfaatkan dan mencari sumber yang relevan, memilih dan menerapkan strategi belajar, mengevaluasi proses dan hasil belajar, dan self-efficacy/konsep diri/kemampuan diri.

Berdasarkan hal tersebut, penelitian ini dilakukan untuk melihat seberapa besar kemampuan penalaran matematis dipengaruhi oleh kemandirian belajar pada materi perbandingan. Hal inilah yang menyebabkan penulis melakukan penelitian apakah kemandirian belajar berpengaruh terhadap kemampuan penalaran matematis siswa. Adapun tujuan penelitian ini adalah untuk mengetahui pengaruh kemandirian belajar terhadap kemampuan penalaran matematis siwa serta besarnya hubungan kemandirian belajar terhadap kemampuan penalaran matematis. 


\section{METODE}

Metode yang digunakan adalah metode korelasi dengan pendekatan kuantitatif yang bertujuan untuk melihat pengaruhi kemandirian belajar terhadap kemampuan penalaran matematis pada materi perbandingan. Populasi dalam penelitian ini adalah siswa SMP/MTs di Kota Cimahi. Sedangkan sampelnya sebanyak 30 orang di MTs Al-Musyahadah Cimahi. Instrumen dalam penelitian ini menggunakan tes dan non tes. Instrumen tes tersebut didasarkan pada penilaian terhadap kemampuan penalaran matematis, sedangkan instrumen non tes didasarkan pada penilaian terhadap kemandirian belajar. Tes kemampuan penalaran sebanyak 6 butir soal uraian pada materi perbandingan yang telah divalidasi dan diuji cobakan serta skala kemandirian belajar siswa sebanyak 32 skala pernyataan. Adapun interpretasi koefisien korelasi nilai r (Riduwan: 2010) sebagai berikut:

$0,00-0,199$ : Sangat Rendah

$0,20-0,399 \quad:$ Rendah

$0,40-0,599$ : Cukup

$0,60-0,799$ : Kuat

$0,80-1,000$ : Sangat Kuat

Namun sebelum dilakukan uji statistika kolerasi, dilakukan terlebih dahulu pengujian normalitas data.

\section{HASIL DAN PEMBAHASAN}

\section{Hasil}

\section{a. Deskripsi Data}

Data penelitian yang digunakan adalah data kemampuan penalaran matematis pada materi perbandingan dan kemandirian belajar siswa MTs Al-Musyahadah Cimahi. Dari data yang diambil dicari nilai rata-rata, median, modus, nilai maksimum, nilai minimum, dan standar deviasi. Deskripsi data disajikan pada Tabel 1 sebagai berikut.

Tabel 1. Deskripsi data Kemampuan Penalaran Matematis dan Kemandirian Belajar

\begin{tabular}{cccccccc}
\hline Kemampuan & $\mathbf{n}$ & $\begin{array}{c}\text { Rata- } \\
\text { rata }\end{array}$ & Modus & Median & $\begin{array}{c}\text { Nilai } \\
\text { Minimum }\end{array}$ & $\begin{array}{c}\text { Nilai } \\
\text { Maksimum }\end{array}$ & $\begin{array}{c}\text { Standar } \\
\text { Deviasi }\end{array}$ \\
\hline $\begin{array}{c}\text { Penalaran } \\
\text { Matematis }\end{array}$ & 30 & 12,07 & 11 & 12 & 0 & 24 & 6,83 \\
\hline $\begin{array}{c}\text { Kemandirian } \\
\text { Belajar }\end{array}$ & 30 & 32,86 & 32 & 56 & 19 & 65 & 28,40 \\
\hline
\end{tabular}

\section{b. Uji Normalitas}

Data terlebih dahulu dilakukan uji normalitas untuk mengetahui apakah data tersebut berdistribusi normal. Statistik uji yang digunakan adalah Kolmogorov Smirnov dengan menggunakan jasa bantuan SPSS. Dalam penelitian ini, uji normalitas dilakukan berdasarkan variabel kemampuan penalaran matematis dan kemandirian belajar siswa, dengan menggunakan hipotesis sebagai berikut.

$\mathrm{H}_{\mathrm{o}}$ : Data berdistribusi normal

$\mathrm{H}_{1}$ : Data tidak berditribusi normal

Rangkuman hasil uji normalitas data disajikan pada Tabel 2 sebagai berikut. 
Tabel 2. Rangkuman Hasil Uji Normalitas

\begin{tabular}{lccc}
\hline & \multicolumn{3}{c}{ Kolmogorov-Smirnov } \\
\cline { 2 - 4 } Kemampuan Penalaran Matematis & .058 & 30 & .200 \\
\hline Kemandirian Belajar & 0.81 & 30 & .200 \\
\hline
\end{tabular}

Karenakan nilai Sig. pada kemampuan penalaran matematis maupun kemandirian belajar dari Kolmogorov-Smirnov menghasilkan nilai 0,200, (Sig. > 0,005) maka $\mathrm{H}_{\mathrm{o}}$ diterima. Sehingga dapat disimpulan bahwa data yang diambil dari tes kemampuan penalaran matematis maupun kemandirian belajar siswa berasal dari populasi yang berdistribusi normal.

\section{c. Uji Kolerasi Product Moment}

Uji kolerasi nilai $r$ (kolerasi) bertujuan untuk mengetahui hubungan antara kemandirian belajar dan kemampuan penalaran matematis siswa. Dalam penelitian ini, uji kolerasi dilakukan menggunakan analisis Kolerasi Pearson Product Moment, dengan rumus berikut (Riduwan: 2010).

$$
r=\frac{N \sum x y-\sum x \sum y}{\sqrt{\left[\left(N \sum x^{2}\right)-\left(\sum x\right)^{2}\right]\left[\left(N \sum y^{2}\right)-\left(\sum y\right)^{2}\right]}}
$$

Dalam pengujian data, dilakukan pengolahan data dengan menggunakan hipotesis sebagai berikut.

Ho : Tidak terdapat hubungan anatara kemampuan penalaran matematis dengan kemandirian belajar siswa.

$\mathrm{H}_{1}$ : Terdapat hubungan anatara kemampuan penalaran matematis dengan kemandirian belajar siswa.

Berdasarkan pada perhitungan diperoleh $r_{\text {hitung }}=0,7572$. Selanjutnya untuk mengetahui apakah terdapat hubungan antara kemampuan penalaran matematis dengan kemandirian belajar siswa, akan dibandingkan dengan nilai $r$ tabel dengan menggunakan taraf signifikan 0,05. Berdasarkan data dari $\mathrm{r}$ tabel dengan $\mathrm{n}-2=30-2=28$ dan $\alpha=0,05$ diperoleh nilai $r_{\text {tabel }}=0,374$. Karena $r_{\text {hitung }}>r_{\text {tabel }}$ atau $0,7572>0,374$ maka $H_{o}$ ditolak, artinya terdapat hubungan antara kemampuan penalaran matematis dengan kemandirian belajar siswa. Dilihat juga dari perhitungan $r_{\text {hitung }}$ sebesar 0,7572 yang berada pada interval $0,60-0,799$ sehingga dikategorikan korelasinya kuat.

\section{d. Uji Kontribusi/Sumbangan}

Untuk menentukan sumbangan kemampuan penalaran matematis dan kemandirian belajar menggunakan rumus:

$$
\mathrm{KP}=\mathrm{r}^{2} \mathrm{x} 100 \% \quad \text { (Riduwan: 2010) }
$$

Berdasarkan perhitungan didapatkan bahwa $\mathrm{KP}=57,33 \%$. Artinya pengaruh kemandirian belajar terhadap kemampuan penalaran matematis siswa sebesar $57,33 \%$ dan sisanya $42,67 \%$ ditentukan oleh faktor lain.

\section{e. Uji Signifikan}

Untuk menguji signifikasi, menggunakan rumus $t_{\text {hitung }}$ (Riduwan: 2010):

$$
t_{\text {hitung }}=\frac{r \sqrt{n-2}}{\sqrt{1-r^{2}}}
$$


Hasil perhitungan data diperoleh thitung: 6,024 dengan $\alpha=0,05 ; \mathrm{db}=\mathrm{n}-2=30-2=28$ sehingga didapat $t_{\text {tabel }}=1,701$. Ternyata $t_{\text {hitung }}>t_{\text {tabel }}$ atau $6,024>1,701$. Maka diperoleh kesimpulan bahwa kolerasi kemampuan penalaran matematis dengan kemandirian belajar adalah signifikan.

\section{Pembahasan}

Dari hasil perhitungan di atas, diperoleh bahwasanya terdapat hubungan yang signifikan antara kemandrian belajar dengan kemampuan penalaran matematis siswa. Dengan demikian kemampuan kognitif matematika dipengaruhi oleh faktor afektif dari individunya (Hidayat, 2017; Dilla, Hidayat, \& Rohaeti, 2018). Seperti hasil yang diperoleh Wijayanti dan Huri (2016) bahwa terdapat pengaruh yang signifikan kecerdasan intrapersonal dan berpikir kritis secara bersam-sama terhadap kemampuan penalaran matematika. Hal ini menunjukkan semakin baik kecerdasan intrapersonal dan berpikir kritis maka akan semakin baik pula kemampuan penalaran matematika peserta didik.

Kemandirian belajar siswa juga dapat membantu mengembangkan kemampuan penalaran matematis. Hal tersebut selaras dengan penelitian yang dilakukan Fitriana (2010) bahwa siswa yang kemandirian belajarnya tinggi memiliki prestasi belajar yang lebih tinggi dibandingkan dengan siswa yang kemandirian belajarnya sedang maupun siswa yang kemandirian belajarnya rendah. Sedangkan penelitian yang dilakukan Rini J, Budiyono, Imam (2014) menyatakan bahwa siswa dengan kemampuan penalaran tinggi mempunyai prestasi belajar lebih baik dibandingkan siswa dengan kemampuan penalaran sedang maupun rendah, dan siswa dengan kemampuan penalaran sedang mempunyai prestasi belajar lebih baik dibandingkan siswa dengan kemampuan penalaran rendah.

Selain itu pula, diketahui bahwasanya kontribusi hubungan antara kemandirian belajar dengan kemapuan penalaran matematis sebesar $57,33 \%$ dan sisanya $42,67 \%$ ditentukan oleh faktor lain. Seperti penggunaan pendekatan atau model pembelajaran tertentu, misalnya pada penelitian yang dilakukan Haerudin (2013) bahwa pendekatan SAVI diasumsikan berpengaruh terhadap peningkatan kemampuan penalaran dan komunikasi matematik serta kemandirian belajar siswa. Tentunya bila pendekatan SAVI dilaksanakan dengan baik dan benar. Kemudian penelitian yang dilakukan Purnamasari (2014) kemandirian belajar peserta didik yang mengikuti pembelajaran Kooperatif Tipe Teams Games-Tournament (TGT) termasuk kualifikasi tinggi, peningkatan kemampuan penalaran dan koneksi matematik peserta didik pada sekolah level tinggi yang mengikuti pembelajaran Kooperatif Tipe Teams Games-Tournament (TGT) lebih baik dibandingkan dengan peningkatan kemampuan penalaran matematik peserta didik yang mengikuti pembelajaran langsung.

\section{KESIMPULAN}

Dari hasil perhitungan dan pembahasan di atas, dapat disimpulkan bahwa:

1. Terdapat hubungan antara kemampuan penalaran matematis siswa dengan kemandirian belajar.

2. Hubungan antara kemandirian belajar dengan kemampuan penalaran matematis dikategorikan kuat.

Pengaruh kemandirian belajar dengan kemapuan penalaran matematis siswa sebesar 57,33\% dan sisanya $42,67 \%$ ditentukan oleh faktor lain. 


\section{DAFTAR PUSTAKA}

Darma, Y., M. Firdaus, R. Haryadi. (2016). Hubungan Kemandirian Belajar terhadap Kemampuan Pemecahan Masalah Matematis Mahasiswa Calon Guru Matematika. Jurnal Edukasi, 14(1): 169-178.

Fitriana, L. (2010). Pengaruh Model Pembelajaran Cooperative Tipe Group Investigation dan STAD terhadap Prestasi belajar Matematika Ditinjau dari Kemandirian Belajar Siswa. (Tesis). Program Studi Pendidikan Matematika, Universitas Sebelas Maret.

Haerudin. (2013). Pengaruh Pendekatan SAVI terhadap Kemampuan Komunikasi dan Penalaran Matematika serta Kemandirian Belajar Siswa SMP. Infinity Jurnal Ilmiah Program Studi Matematika STKIP Siliwangi Bandung, 2(2): 183-193.

Hendriana, H., Rohaeti, E. E., Sumarmo, U. (2017). Hard Skills dan Soft Skills Matematik Siswa. Bandung: PT Refika Aditama.

Hidayat, W. (2017). Adversity Quotient dan Penalaran Kreatif Matematis Siswa SMA dalam Pembelajaran Argument Driven Inquiry pada Materi Turunan Fungsi. KALAMATIKA Jurnal Pendidikan Matematika, 2(1), 15-28.

Hidayat, W., \& Prabawanto, S. (2018). Improving students' creative mathematical reasoning ability students through adversity quotient and argument driven inquiry learning. In Journal of Physics: Conference Series, 948(1), 012005.

Isnaeni, S., Fajriyah, L., Risky, E. S., Purwasih, R., \& Hidayat, W. (2018). Analisis Kemampuan Penalaran Matematis dan Kemandirian Belajar Siswa SMP pada Materi Persamaan Garis Lurus. Journal of Medives, 2(1), 107-116.

Nuridawani, Said, M., Saiman. (2015). Peningkatan Kemampuan Penalaran Matematis dan Kemandirian Belajar Siswa Madrasah Tsanawiyah (MTs) melalui Pendekatan Contextual Teaching and Learning (CTL). Jurnal Didaktik Matematika, 2(2): 59-71.

Purnamasari, Y. (2014). Pengaruh Model Pembelajaran Kooperatif Tipe Teams Games Tournament (TGT) terhadap Kemandirian Belajar dan Peningkatan Kemampuan Penalaran dan Koneksi Matematik Peserta Didik SMPN 1 Kota Tasikmalaya. Jurnal Pendidikan dan Keguruan, 1(1): artikel 2.

Riduwan. (2010). Dasar-Dasar Statistika. Bandung: ALFABETA.

Rini, J., Budiyono, Imam S. (2014). Eksperimentasi Model Pembelajaran Berbasis Masalah dan Problem Posing pada Materi Bangun Ruang Sisi Datar Ditinjau dari Kemampuan Penalaran Siswa Kelas VIII SMP Negeri di Kabupaten Banyumas Tahun Pelajaran 2013/2014. Jurnal Elektronik Pembelajaran Matematika, 2(8): 779-790.

Dilla, S. C., Hidayat, W., \& Rohaeti, E. E. (2018). Faktor Gender dan Resiliensi dalam Pencapaian Kemampuan Berpikir Kreatif Matematis Siswa SMA. Journal of Medives, 2(1), 129-136.

Wijayanti, H., Huri. (2016). Pengaruh Kecerdasan Intrapersonal dan Berpikir Kritis terhadap Kemampuan Penalaran Matematika. Prosiding Diskusi Panel Nasional Pendidikan Matematika. Jakarta, FTMIPA Universitas Indraprasta PGRI: 240-248.

Zannati, G. N. (2017). Analisis Kemampuan Penalaran Matemtis Siswa pada Materi Bangun Datar di MTs Al-Musyahadah, Prosiding Seminar Nasional Matematika dan

Pendidikan Matematika STKIP Siliwangi. Bandung, STKIP Siliwangi: 1585-1593. 